\title{
SUGARCANE GROWN IN AN OXISOLAMENDED WITH SEWAGE SLUDGE AND VINASSE: NITROGEN CONTENTS IN SOIL AND PLANT
}

\author{
Ademir Francoㅎ Marcos Omir Marques²*; Wanderley José de Melo ${ }^{3}$ \\ ${ }^{1}$ UNESP/FCAVJ - Programa de Pós-Graduação em Agronomia. \\ ${ }^{2}$ UNESP/FCAVJ - Depto. de Tecnologia - Lab. de Tecnologia do Açúcar e Álcool, Via de Acesso Professor Paulo \\ Donato Castellane, s/n - 14884-900 - Jaboticabal, SP - Brasil. \\ ${ }^{3}$ UNESP/FCAVJ - Depto. de Tecnologia - Lab. de Bioquímica de Solo. \\ *Corresponding author <omir@fcav.unesp.br>
}

ABSTRACT: Sewage sludge is a residue from waste water treatment plants and vinasse is a main effluent from alcohol distilleries. The main differences between them are observed in the nitrogen (N) and potassium $(\mathrm{K})$ contents. Sewage sludge is poor in $\mathrm{K}$, and the vinasse in N. This research was carried out to evaluate sewage sludge and vinasse effects on the nitrogen contents of the plant-soil system and the effects of their application on planted-cane and $1^{\text {st. }}$ ratoon-cane under field conditions, on a Typic Haplustox, in Pontal, State of São Paulo, Brazil, using the sugarcane cultivar SP81-3250. A randomized blocks experimental design was used with 13 treatments and three replications. The results were organized in a $3 \times 2 \times 2$ factorial scheme (three residue forms, two application modes and two rates of $\mathrm{N}$ or $\mathrm{K}$ ) and a control treatment (mineral fertilization). Sewage sludge provided the highest $\mathrm{N}$ plant contents and the highest residual $\mathrm{N}$ soil contents. Sewage sludge and vinasse can replace mineral fertilization for both planted-cane and $1^{\text {st. }}$ ratoon-cane.

Key words: agricultural reuse, residue, productivity, vinasse, sludge

\section{CANA-DE-AÇÚCAR CULTIVADANUM LATOSSOLO QUE RECEBEU LODO DE ESGOTO E VINHAÇA: TEORES DE NITROGÊNIO NO SOLO E NA PLANTA}

\begin{abstract}
RESUMO: O lodo de esgoto é um resíduo obtido em Estações de Tratamento de Esgoto. A vinhaça constitui-se no principal efluente das destilarias de álcool. A principal diferença entre ambos está nos conteúdos de nitrogênio $(\mathrm{N})$ e potássio $(\mathrm{K})$, sendo o lodo de esgoto pobre em $\mathrm{K}$ e a vinhaça pobre em N. O objetivo deste trabalho foi avaliar o efeito do lodo de esgoto e da vinhaça sobre o nitrogênio no sistema solo-planta e os reflexos na produtividade da cana-de-açúcar por dois anos consecutivos. O experimento foi conduzido em um Latossolo Vermelho Amarelo Distrófico plintico, localizado no Município de Pontal, SP. A cultivar de cana-de-açúcar testada foi a SP81-3250. Os fatores de estudo foram três resíduos (lodo de esgoto, vinhaça e lodo de esgoto+vinhaça), dois modos de aplicação (linha de plantio e área total), duas doses (100 e 200\% do N e K necessários à cultura) e um tratamento testemunha (adubação mineral). O lodo de esgoto proporcionou maior acúmulo de $\mathrm{N}$ na planta e maior teor residual de $\mathrm{N}$ no solo. A aplicação de lodo de esgoto e vinhaça na cultura da cana-de-açúcar pode substituir a adubação mineral, tanto para cana-planta quanto para cana-soca.

Palavras-chave: reuso agrícola, resíduo, produtividade, vinhoto, esgoto
\end{abstract}

\section{INTRODUCTION}

The municipal waste water treatment produces a gummy material, consisting of organic matter, water and mineral elements, called sewage sludge. About 33 to $50 \%$ of the total nitrogen from the sewage sludge is available to plants in the first year after soil amendment (Marques, 1996). Soil nitrogen suffers rapid alterations in the soil depending on organic matter content, aeration, moisture, temperature and nutrients, and therefore it is very difficult to estimate soil nitrogen availability to plants, several evaluation methods being in discussion (Gianello et al., 2000). For sewage sludge it is very important to know the rate of transfer of its nitrogen to plants in order to reduce application rates and diminish the risk of environmental pollution.

Vinasse is a residue from alcohol distilleries generated in great amounts (12-15 liters per liter of alcohol), containing water, organic matter, macronutrients, mainly K, and other trace elements (Rosseto, 1987). 
The area cropped with sugarcane (Saccharum spp.) in Brazil is about 6 million hectares and most of them are suitable to receive residues. Sugarcane producers know how to use residues with low risks to the environment. The sugarcane crop undergoes mainly the industrialization process, which diminishes the direct risk to man and animal health and to environment pollution. The objective of this study was to evaluate the use of residues, alone or combined, as sources of $\mathrm{N}$ and $\mathrm{K}$ for the sugarcane plant, focusing the effects of rates and application forms on yield, soil and plant $\mathrm{N}$, also considering the transfer rate of the nutrients from the sewage sludge to the sugarcane plant.

\section{MATERIALAND METHODS}

The experiment was set up on April 7, 2000,

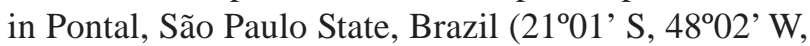
$515 \mathrm{~m}$ altitude), on a Typic Haplustox with the following chemical characteristics: $\mathrm{pH}\left(\mathrm{CaCl}_{2} 0.01 \mathrm{~mol}\right.$ $\left.\mathrm{L}^{-1}\right)=5.0$, organic matter $(\mathrm{OM})=25 \mathrm{~g} \mathrm{dm}^{-3}$, Kjeldahl$\mathrm{N}=1.31 \mathrm{~g} \mathrm{~kg}^{-1}, \mathrm{P}=20 \mathrm{mg} \mathrm{dm}^{-3}, \mathrm{~K}=1.2 \mathrm{mmol}_{\mathrm{c}} \mathrm{dm}^{-3}$, $\mathrm{Ca}=20 \mathrm{mmol}_{\mathrm{c}} \mathrm{dm}^{-3}, \mathrm{Mg}=6 \mathrm{mmol}_{\mathrm{c}} \mathrm{dm}^{-3}, \mathrm{H}+\mathrm{Al}=28$ mmol $\mathrm{dm}^{-3}$. The area used in this experiment was under rest during the last ten years.

The sugarcane cultivar used as test plant was the SP81-3250. Sewage sludge presented the chemical composition shown in Table 1. Vinasse came from wine distillation made in a conventional distillation apparatus and analyzed by the same methods used for the sewage sludge. Its chemical composition is shown in Table 1.

The treatments resulted from the combination of three types of amendments: sewage sludge, vinasse and sewage sludge + vinasse; two application methods: in the planting furrow for the planted-cane or spread on the soil surface at the side of the plants for the $1^{\text {st }}$ ratoon-cane, and spread on the total area for both the croppings; and two application rates: sewage sludge to supply 100 and $200 \%$ of the nitrogen requirement and vinasse to supply 100 and $200 \%$ of the potassium requirement. A control treatment was also used, which received limestone and mineral fertiliza- tion according to Raij et al. (1996). The other nutrients were supplied by mineral fertilization. The experiment was installed in a randomized block design arranged in a $3 \times 2 \times 2$ factorial scheme, with an additional control and three replications. Each experimental plot contained five $10 \mathrm{~m}$ long sugarcane rows spaced by $1.50 \mathrm{~m}$ and the useful area was formed by the three central rows, discarding $1 \mathrm{~m}$ at each row end.

The equivalent rates corresponded to 5 and 10 $\mathrm{t} \mathrm{ha}{ }^{-1}$ sewage sludge (dry basis), 115 and $230 \mathrm{~m}^{3} \mathrm{ha}^{-1}$ of vinasse for the palnted-cane; 7 and $14 \mathrm{t} \mathrm{ha}^{-1}$ sewage sludge (dry basis), 117 and $234 \mathrm{~m}^{3}$ ha $^{-1}$ vinasse for the $1^{\text {st }}$ ratoon-cane. For the $1^{\text {st }}$ ratoon-cane, the rates were calculated based on soil the chemical analysis made after the planted-cane harvest in the control treatment, which was: $\mathrm{pH}\left(\mathrm{CaCl}_{2}\right)=4.7 ; \mathrm{OM}=24 \mathrm{~g} \mathrm{dm}^{-3}$; $\mathrm{P}=10 \mathrm{mg} \mathrm{dm}^{-3} ; \mathrm{K}=0.8 \mathrm{mmol}_{\mathrm{c}} \mathrm{dm}^{-3} ; \mathrm{Ca}=25 \mathrm{mmol}_{\mathrm{c}}$ $\mathrm{dm}^{-3} ; \mathrm{Mg}=7 \mathrm{mmol}_{\mathrm{c}} \mathrm{dm}^{-3} ; \mathrm{H}+\mathrm{Al}^{\mathrm{c}}=64 \mathrm{mmol}_{\mathrm{c}} \mathrm{dm}^{-3}$. The plots of the $1^{\text {st }}$ ratoon-cane control were limed with $1.8 \mathrm{t} \mathrm{ha}^{-1}$ dolomitic limestone. The treatments with sewage sludge alone were complemented with $\mathrm{K}$ (potassium chloride) and the treatments with vinasse alone were complemented with nitrogen (urea).

Plants were sampled for chemical analysis in June, 28, 2001 (planted-cane) and August, 3, 2002 (ratoon-cane) collecting three plants from the useful area. Plants were washed, separated in leaves, stalk and heart, and weighed. The stalks were shredded, homogenized and samples were dried in a forced air oven at $60-70^{\circ} \mathrm{C}$ until constant weight, weighed, ground and analyzed for Kjeldahl-N (Sarruge \& Haag, 1974).

For harvest, the plants in the useful area of the plots were burnt (as usually done in Brazilian tradicional harvests), harvested (July, 5, 2001 for the planted-cane and August, 8, 2002 for the $1^{\text {st }}$ ratoon-cane) and weighed. The sugarcane yield was obtained adding to this weight the weight of the stalks collected for chemical analysis. Soil samples were collected after harvest on the planting rows and between-rows, at the depths 0-20, 20-40 and 40-60 cm, air dried, sieved (2 $\mathrm{mm}$ ) and analyzed for Kjeldahl-N (Melo, 1974).

The transfer rate of nitrogen from the sewage sludge to the sugarcane; (T\%) was estimated by:

Table 1 - Chemical composition of the sewage sludge and the vinasse

\begin{tabular}{|c|c|c|c|c|c|c|c|c|c|}
\hline Residue & $\mathrm{N}$ & $\mathrm{P}$ & $\mathrm{K}$ & $\mathrm{Ca}$ & $\mathrm{Mg}$ & $\mathrm{Cu}$ & $\mathrm{Mn}$ & $\mathrm{Zn}$ & $\mathrm{Fe}$ \\
\hline Sewage sludge & -..--- & (n) & $\mathrm{g} \mathrm{kg}^{-1}$ & & (n-... & $-\ldots$ & ---- & $\mathrm{kg}^{-1}-\mathrm{C}^{--}$ & --- \\
\hline Planted-cane & 79.5 & 10.6 & 0.63 & nd & nd & 225 & 400 & 1,000 & 26,391 \\
\hline $1^{\text {st }}$ ratoon-cane & 52 & 3.4 & 1.96 & 4.25 & 0.56 & 380 & 98 & 658 & 29,350 \\
\hline Vinasse & $-\ldots$ & $\cdots$ & 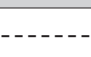 & & - $\mathrm{mg}$ & -- & $\cdots$ & 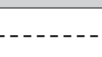 & $\ldots$ \\
\hline Planted-cane & 0.35 & 0.13 & 1.39 & 0.42 & 0.07 & 0.17 & 4.48 & 0.82 & 59.89 \\
\hline $1^{\text {st }}$ ratoon-cane & 0.29 & 0.20 & 1.11 & 0.85 & 0.22 & 0.12 & 4.21 & 0.76 & 63.42 \\
\hline
\end{tabular}

nd = not determined. 


$$
\mathrm{T} \%=\frac{N c}{N s+N l-N r} * 100
$$

where Nc = plant nitrogen $\left(\mathrm{kg} \mathrm{ha}^{-1}\right)$; Ns = soil nitrogen before sewage sludge application $\left(\mathrm{kg} \mathrm{ha}^{-1}\right) ; \mathrm{Nl}=$ nitrogen added by sewage sludge $\left(\mathrm{kg} \mathrm{ha}^{-1}\right) ; \mathrm{Nr}=$ soil nitrogen after sugarcane cropping $\left(\mathrm{kg} \mathrm{ha}^{-1}\right)$.

To calculate sugarcane nitrogen only the contents of the stalk were considered. The data were submitted to the variance analysis ( $F$ test) and the Tukey test was used for mean comparison $(p<0.05)$ when the $\mathrm{F}$ test was significant.

\section{RESULTS AND DISCUSSION}

\section{Soil nitrogen}

The residual Kjeldahl-N after planted-cane cropping (Table 2) was not affected by the treatments in all positions or sampling depths, as also reported by Oliveira (2000). Considering that 55\% of the sugarcane roots are located in a $30 \mathrm{~cm}$ radius from the planting line (Sampaio et al., 1987), it was expected that the residual $\mathrm{N}$ should be higher between lines, a fact that was really observed. Kjeldahl-N ranged from $597 \mathrm{mg} \mathrm{kg}^{-1}$ (40-60 cm layer) to $1190 \mathrm{mg} \mathrm{kg}^{-1}(0-20$ $\mathrm{cm}$ layer) for samples from between rows. Oliveira et al. (2001) also found a decrease in total-N with soil depth in an Oxisol. Lara Cabezas et al. (1994) applied vinasse and urea to an Oxisol and an Ultisol and found total- $\mathrm{N}$ contents ranging from 167 to $563 \mathrm{mg} \mathrm{kg}^{-1}$, highlighting the importance of the nature of the soil on total-N content.

The lack of differences among residue types and application methods suggested that the mineral fertilization of planted-cane could be completely replaced by correctly applied residues.

The nutrients in the residues were in the organic form, so that they become available to plants only after mineralization. The residual contents of $\mathrm{N}$ in the samples collected on the planting rows were not different among treatments, regardless of the depth. This suggests that for the treatments that received higher levels of waste the losses of $\mathrm{N}$ were higher despite the fact that the $\mathrm{N}$ concentration in the stalks of the plants that received more $\mathrm{N}$ were also higher (Table 4). This behavior is different from that observed by

Table 2 - Kjeldahl-N in soil samples after applying sewage sludge and vinasse to planted-cane.

\begin{tabular}{|c|c|c|c|c|c|c|}
\hline \multirow[b]{3}{*}{ Factors } & \multicolumn{3}{|c|}{ Row } & \multicolumn{3}{|c|}{ Between-rows } \\
\hline & \multicolumn{6}{|c|}{ Depth $\overline{(\mathrm{cm})}$} \\
\hline & $0-20$ & $20-40$ & $40-60$ & $0-20$ & $20-40$ & $40-60$ \\
\hline & \multicolumn{6}{|c|}{ (n- } \\
\hline Control (C) & 1,013 & 1,013 & 835 & 1,190 & 882 & 597 \\
\hline Factorial $(\mathrm{F})$ & 935 & 933 & 865 & 1,089 & 1,009 & 658 \\
\hline Sewage Sludge (SS) & 991 & 963 & 886 & 1,077 & 1,054 & 674 \\
\hline Vinasse (V) & 979 & 981 & 821 & 1,049 & 991 & 659 \\
\hline $\mathrm{SS}+\mathrm{V}$ & 837 & 855 & 889 & 1,141 & 984 & 639 \\
\hline Furrow & 919 & 933 & 887 & 1,059 & 1,033 & 640 \\
\hline Total Area & 952 & 933 & 844 & 1,118 & 985 & 675 \\
\hline $100 \%$ rate & 940 & 954 & 878 & 1,038 & 1,020 & 635 \\
\hline $200 \%$ rate & 931 & 912 & 852 & 1,140 & 999 & 681 \\
\hline \multicolumn{7}{|l|}{ Statistic (F test) } \\
\hline Blocks & $1.02^{\mathrm{NS}}$ & $1.17^{\mathrm{NS}}$ & $0.07^{\mathrm{NS}}$ & $0.16^{\mathrm{NS}}$ & $1.00^{\mathrm{NS}}$ & $5.31^{\mathrm{NS}}$ \\
\hline $\mathrm{F} \times \mathrm{C}$ & $0.44^{\mathrm{NS}}$ & $0.50^{\mathrm{NS}}$ & $0.07^{\mathrm{NS}}$ & $0.68^{\mathrm{NS}}$ & $1.78^{\mathrm{NS}}$ & $1.09^{\mathrm{NS}}$ \\
\hline Residues (R) & $2.37^{\mathrm{NS}}$ & $1.59^{\mathrm{NS}}$ & $0.52^{\mathrm{NS}}$ & $0.65^{\mathrm{NS}}$ & $0.71^{\mathrm{NS}}$ & $0.40^{\mathrm{NS}}$ \\
\hline Application Mode (AM) & $0.27^{\mathrm{NS}}$ & $0.00^{\mathrm{NS}}$ & $0.49^{\mathrm{NS}}$ & $0.76^{\mathrm{NS}}$ & $0.81^{\mathrm{NS}}$ & $1.20^{\mathrm{NS}}$ \\
\hline Rates (Rt) & $0.02^{\mathrm{NS}}$ & $0.44^{\mathrm{NS}}$ & $0.18^{\mathrm{NS}}$ & $2.28^{\mathrm{NS}}$ & $0.16^{\mathrm{NS}}$ & $2.06^{\mathrm{NS}}$ \\
\hline $\mathrm{R} \times \mathrm{AM}$ & $1.85^{\mathrm{NS}}$ & $1.54^{\mathrm{NS}}$ & $1.45^{\mathrm{NS}}$ & $0.34^{\mathrm{NS}}$ & $0.41^{\mathrm{NS}}$ & $0.04^{\mathrm{NS}}$ \\
\hline $\mathrm{R} \times \mathrm{Rt}$ & $0.37^{\mathrm{NS}}$ & $0.16^{\mathrm{NS}}$ & $0.74^{\mathrm{NS}}$ & $0.47^{\mathrm{NS}}$ & $0.01^{\mathrm{NS}}$ & $0.90^{\mathrm{NS}}$ \\
\hline $\mathrm{AM} \times \mathrm{Rt}$ & $0.43^{\mathrm{NS}}$ & $0.62^{\mathrm{NS}}$ & $2.30^{\mathrm{NS}}$ & $0.61^{\mathrm{NS}}$ & $0.86^{\mathrm{NS}}$ & $0.10^{\mathrm{NS}}$ \\
\hline $\mathrm{R} \times \mathrm{AM} \times \mathrm{Rt}$ & $1.63^{\mathrm{NS}}$ & $3.08^{\mathrm{NS}}$ & $0.01^{\mathrm{NS}}$ & $0.13^{\mathrm{NS}}$ & $0.11^{\mathrm{NS}}$ & $1.68^{\mathrm{NS}}$ \\
\hline $\mathrm{CV}(\%)$ & 20.51 & 19.92 & 21.22 & 18.58 & 15.85 & 14.70 \\
\hline
\end{tabular}

NS - not significant. 
Table 3 - Kjeldahl-N in soil samples collected after applying sewage sludge and vinasse to $1^{\text {st }}$ ratoon-cane.

\begin{tabular}{|c|c|c|c|c|c|c|}
\hline \multirow[b]{3}{*}{ Factors } & \multicolumn{3}{|c|}{ Row } & \multicolumn{3}{|c|}{ Between-rows } \\
\hline & \multicolumn{6}{|c|}{ Depth $(\mathrm{cm})$} \\
\hline & $0-20$ & $20-40$ & $40-60$ & $0-20$ & $20-40$ & $40-60$ \\
\hline \multicolumn{7}{|c|}{ - } \\
\hline Control (C) & 859 & 985 & 535 & 1.055 & 974 & 513 \\
\hline Factorial $(\mathrm{F})$ & 1,187 & 955 & 587 & 1,077 & 965 & 553 \\
\hline Sewage sludge (SS) & $1,275^{\mathrm{A}}$ & 963 & $558^{\mathrm{B}}$ & 1,118 & 922 & 533 \\
\hline Vinasse (V) & $974^{\mathrm{B}}$ & 911 & $484^{\mathrm{B}}$ & 1,054 & 912 & 527 \\
\hline $\mathrm{SS}+\mathrm{V}$ & $1,311^{\mathrm{A}}$ & 991 & $720^{\mathrm{A}}$ & 1,061 & 981 & 599 \\
\hline Side of the plants & $1,324^{\mathrm{A}}$ & 990 & 639 & 1,069 & 976 & 546 \\
\hline Total area & $1,050^{\mathrm{B}}$ & 919 & 535 & 1,085 & 922 & 560 \\
\hline $100 \%$ rate & 1,109 & 858 & 533 & 1,022 & 902 & 515 \\
\hline $200 \%$ rate & 1,265 & 1,052 & 642 & 1,132 & 1,065 & 591 \\
\hline \multicolumn{7}{|l|}{ Statistic (F test) } \\
\hline Blocks & $0.13^{\mathrm{NS}}$ & $8.36 * *$ & $2.58^{\mathrm{NS}}$ & $2.55^{\mathrm{NS}}$ & $1.69^{\mathrm{NS}}$ & $0.87^{\mathrm{NS}}$ \\
\hline $\mathrm{F} \times \mathrm{C}$ & $5.76^{*}$ & $0.06^{\mathrm{NS}}$ & $0.20^{\mathrm{NS}}$ & $0.02^{\mathrm{NS}}$ & $0.44^{\mathrm{NS}}$ & $0.40^{\mathrm{NS}}$ \\
\hline Residues (R) & $7.94 * *$ & $0.46^{\mathrm{NS}}$ & $4.07^{*}$ & $0.23^{\mathrm{NS}}$ & $0.82^{\mathrm{NS}}$ & $1.74^{\mathrm{NS}}$ \\
\hline Application (AM) & $13.03 * *$ & $1.06^{\mathrm{NS}}$ & $2.28^{\mathrm{NS}}$ & $0.03^{\mathrm{NS}}$ & $2.39^{\mathrm{NS}}$ & $0.16^{\mathrm{NS}}$ \\
\hline Rates (Rt) & $4.21^{\mathrm{NS}}$ & $7.95 * *$ & $2.49^{\mathrm{NS}}$ & $1.73^{\mathrm{NS}}$ & $1.20^{\mathrm{NS}}$ & $4.85^{\mathrm{NS}}$ \\
\hline $\mathrm{R} \times \mathrm{AM}$ & $4.68 *$ & $0.43^{\mathrm{NS}}$ & $1.51^{\mathrm{NS}}$ & $1.83^{\mathrm{NS}}$ & $0.61^{\mathrm{NS}}$ & $0.83^{\mathrm{NS}}$ \\
\hline $\mathrm{R} \times \mathrm{Rt}$ & $1.99^{\mathrm{NS}}$ & $0.82^{\text {NS }}$ & $2.37^{\mathrm{NS}}$ & $0.09^{\mathrm{NS}}$ & $0.12^{\mathrm{NS}}$ & $1.27^{\mathrm{NS}}$ \\
\hline AM. $\times$ Rt & $0.20^{\mathrm{NS}}$ & $1.21^{\mathrm{NS}}$ & $0.40^{\mathrm{NS}}$ & $0.03^{\mathrm{NS}}$ & $1.33^{\mathrm{NS}}$ & $0.58^{\mathrm{NS}}$ \\
\hline $\mathrm{R} . \times \mathrm{AM} \times \mathrm{Rt}$ & $0.08^{\mathrm{NS}}$ & $2.99^{\mathrm{NS}}$ & $1.12^{\mathrm{NS}}$ & $1.82^{\mathrm{NS}}$ & $5.03^{\mathrm{NS}}$ & $0.44^{\mathrm{NS}}$ \\
\hline $\mathrm{VC}(\%)$ & 19.58 & 21.52 & 35.51 & 23.45 & 12.04 & 18.88 \\
\hline
\end{tabular}

NS not significant; *significant at $p<0.05$;** - significant at $p<0.001$.

Table 4 - Kjeldhal-N in different parts of plants treated with combinations of sewage sludge and vinasse.

\begin{tabular}{|c|c|c|c|c|c|c|}
\hline \multirow[b]{2}{*}{ Factors } & \multicolumn{3}{|c|}{ Planted-Cane } & \multicolumn{3}{|c|}{$1^{\text {st }}$ Ratoon-Cane } \\
\hline & Leaves & Stalks & Hearts & Leaves & Stalks & Hearts \\
\hline & $-\cdots-\cdots$ & $-\cdots--$ & -..-- & -...- & $-\cdots--1$ & ---n-- \\
\hline Control & 9.06 & 2.36 & 20.97 & 12.17 & 3.29 & 23.34 \\
\hline Factorial & 8.62 & 2.18 & 23.62 & 12.14 & 3.32 & 22.21 \\
\hline Sewage sludge (SS) & 8.77 & 2.28 & 22.32 & 12.51 & 3.42 & 23.43 \\
\hline Vinasse (V) & 8.50 & 2.15 & 23.92 & 11.57 & 3.33 & 21.00 \\
\hline$(\mathrm{SS})+(\mathrm{V})$ & 8.60 & 2.12 & 24.91 & 12.33 & 3.20 & 22.20 \\
\hline Furrow/Side of the plants & 8.50 & 2.16 & 21.51 & 12.34 & 3.51 & 21.93 \\
\hline Total area & 8.75 & 2.21 & 25.73 & 11.93 & 3.13 & 22.49 \\
\hline $100 \%$ rate & 8.44 & $1.91^{\mathrm{B}}$ & 21.75 & 12.02 & 3.50 & 21.81 \\
\hline $200 \%$ rate & 8.81 & $2.46^{\mathrm{A}}$ & 25.49 & 12.25 & 3.13 & 22.61 \\
\hline
\end{tabular}

Araújo et al. (2001), who reported no reduction in the mineralization potential in a study of 10 years.

After the $1^{\text {st }}$ ratoon-cane cropping, Kjeldahl-N in the planting row of the control treatment tended to be lower at $0-20 \mathrm{~cm}$ compared to $20-40 \mathrm{~cm}$ (Table
3), probably caused by the greater concentration of the roots at that depth (Sampaio et al., 1987) associated to a greater mineralization rate of the organic-N in the surface layers (Salcedo et al., 1985) and a possible $\mathrm{N}$ leaching. Kjeldahl-N between-rows tended to 
increase, because the exploration of this area by sugarcane roots is less intense even in the top soil and decreased in the deeper layers, as similarly found after planted-cane cropping.

Soil $\mathrm{N}$ after the $1^{\text {st }}$ ratoon-cane cropping varied from $513 \mathrm{mg} \mathrm{kg}^{-1}$ (between rows, 40-60 cm depth) to $1,187 \mathrm{mg} \mathrm{kg}^{-1}$ (on planting rows, $0-20 \mathrm{~cm}$ depth). Similar results were obtained by Oliveira et al. (2001) after planted-cane cropping.

The highest Kjeldahl- $\mathrm{N}$ in the planting rows after the ratoon-cane cropping occurred in the treatments with sewage sludge or sewage sludge+vinasse. This is expected since for calculating the rates of sewage sludge to be applied only $1 / 3$ of the $\mathrm{N}$ was considered to be mineralized (Berton, 2000) in the first year. In this way, and considering that $10-20 \%$ of the $\mathrm{N}$ from the first application was mineralized during the ratoon-cane development (Andreoli et al., 1997), at least the double of the $\mathrm{N}$ required for sugarcane growth would remain in the soil.

Residual N, when the residues were applied into or at the side of planting rows, was higher than when the application was on the total area. This can be explained by the fact of this localized form of residue application which concentrates the nutrient at the sampling place. It may be considered that this $\mathrm{N}$ will be, at least in part, absorbed by the next ratoon-cane, since it is in the root zone, a decisive factor according to Sampaio et al. (1987).

\section{Plant nitrogen}

$\mathrm{N}$ in the different parts of the plants was not affected by the type and form of residue application, but the rates affected the content in the stalks (Table 4). In an experiment with sewage sludge, Dias (1994) found higher $\mathrm{N}$ content in plants treated with the residue as compared to plants treated with mineral fertilizers.

Leaf $\mathrm{N}$ contents in the planted-cane ranged from 8.6 and $9.0 \mathrm{~g} \mathrm{~kg}^{-1}$ and around $12.1 \mathrm{~g} \mathrm{~kg}^{-1}$, in the $1^{\text {st }}$ ratoon-cane. In a study with sewage sludge application, Marques (1996) applied rates of 0, 10, 20 and $40 \mathrm{t} \mathrm{ha}^{-1}$ of sewage sludge (dry basis) and reported leaf $\mathrm{N}$ contents between 7.0 and $8.2 \mathrm{~g} \mathrm{~kg}^{-1}$ for plantedcane. Silva et al. (1998) reported that the $\mathrm{N}$ content determined in the +3 leaf was $8.5 \mathrm{~g} \mathrm{~kg}^{-1}$ for the $1^{\mathrm{st}}$ ratoon-cane.

The $\mathrm{N}$ contents in the stalks varied between 2.18 and $2.36 \mathrm{~g} \mathrm{~kg}^{-1}$ the planted-cane and between 3.13 to $3.3 \mathrm{~g} \mathrm{~kg}^{-1}$ in the $1^{\text {st }}$ ratoon-cane. Marques (1996) reported contents between 1.3 and $2.2 \mathrm{~g} \mathrm{~kg}^{-1}$ in a study with increasing rates of sewage sludge. According to Humbert (1984), the critical $\mathrm{N}$ level in this part of the plant is $2.5 \mathrm{~g} \mathrm{~kg}^{-1}$ and that values up to $60 \mathrm{~g} \mathrm{~kg}^{-1}$ are considered normal. In the hearts, the detected values for $\mathrm{N}$ oscillated form 21 to $23.6 \mathrm{~g} \mathrm{~kg}^{-1}$ in planted-cane and from 22.2 to $23.34 \mathrm{~g} \mathrm{~kg}^{-1}$ in $1^{\text {st }}$ ratoon-cane, which are higher than those reported by Marques (1996).

In planted-cane, the content of $\mathrm{N}$ in the different parts of the plant tended to be higher when the residues were applied on the total area, while in the $1^{\text {st }}$ ratoon-cane this tendency occurred when the residues were applied in the planting rows (Table 4). This behavior is explained by the poorer root system of the $1^{\text {st }}$ ratoon-cane, which depends on the proximity of the fertilizer for its absorption (Carnauba, 1990).

$\mathrm{N}$ accumulated in planted-cane stalks was not affected by the treatments but in the 1st ratoon-cane it was higher when sewage sludge was applied (Figure 1). $\mathrm{N}$ assimilation was greater when the residues were applied at the side of the planting rows $\left(1^{\text {st }}\right.$ ratoon-cane) as compared to the application on total area, confirming the weak root system vigor of the $1^{\text {st }}$ ratoon-cane, which is more dependent on the proximity of the applied fertilizers (Carnaúba, 1990).

\section{Soil-plant system nitrogen}

Considering the initial soil Kjeldahl $\mathrm{N}$ content of 2,616 kg ha-1 in the 0.0-0.20 m layer and through the equation (1), and based on the data presented in the Tables 1, 2, 3, 4 and 5, the $\mathrm{N}$ transfer rate (T\%) was estimated for the planted-cane and $1^{\text {st }}$ ratoon-cane plants: 33.11 and $16.40 \%$, respectively. Trivelin (2000) assessed the contribution of the nitrogen fertilizer to planted-cane with the use of ${ }^{15} \mathrm{~N}$, and ascertained that mineral fertilization represented $11.5 \%$ of the total $\mathrm{N}$ accumulated by the plant. Values lower than $10 \%$ were

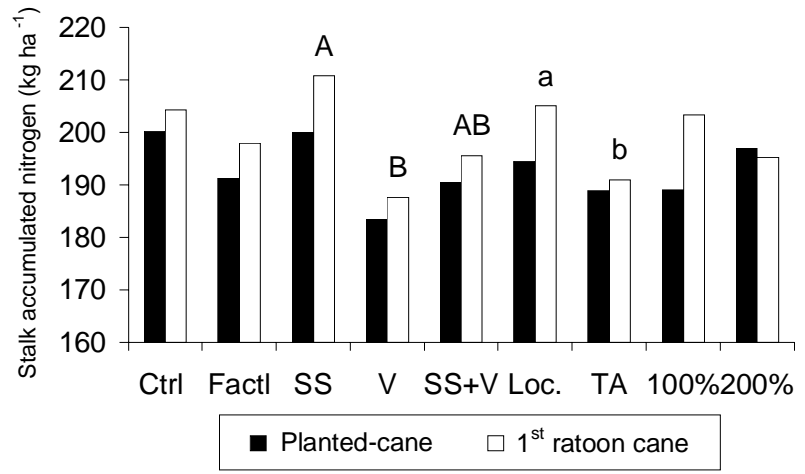

Figure 1 - Kjeldahl-N accumulated in sugarcane plants cultivated in soil amended with sewage sludge and vinasse.

Ctrl - control, Factl - mean of the plots in the factorial design, SS - sewage sludge, $\mathrm{V}$ - vinasse, $\mathrm{SS}+\mathrm{V}$ - sewage sludge + vinasse, Loc - located application, TA - total area application, $100 \%$ (NK=100 \%), 200\% (NK=200\%). Uppercase compares types of residues and lowercase compares application methods (Tukey's test, $p<0.005$ ). 
reported by Sampaio et al. (1987). Carnaúba (1990) and Gava et al. (2001) also used ${ }^{15} \mathrm{~N}$ and ascertained that for $1^{\text {st }}$ ratoon-cane the contribution of the fertilizer to sugarcane nitrogen was 14 and $22 \%$.

The results let us to conclude that the method used to estimate the contribution of sewage sludge to sugarcane was very simple and agreed with the more complex and expensive methods as those that use ${ }^{15}$ N. Finally, the tested residues, except vinasse alone, showed a potential supply to all the nitrogen required by the crop, independently of the application form or rate.

Yield

The mean yield for planted-cane and the $1^{\text {st }}$ ratoon-cane were 125.5 and $100.0 \mathrm{t} \mathrm{ha}^{-1}$, respectively (Table 5), as expected for this cultivar (Copersucar, 1995). Planted-cane yield was not affected by the studied factors, that is, there was no difference between mineral fertilization and any of the residue combinations. Similar results were obtained by Marques (1996), who applied 10, 20 and $40 \mathrm{t} \mathrm{ha}^{-1}$ sewage sludge (dry basis), and Oliveira (2000), who applied 33, 66, and $99 \mathrm{t} \mathrm{ha}^{-1}$ sewage sludge.

Yield was higher for the $1^{\text {st }}$ ratoon-cane when sewage sludge was applied (sewage sludge and sewage sludge + vinasse), a fact that could be attributed to the greater $\mathrm{N}$ accumulation in the plant (Figure 1), by the high potential of the sewage sludge to supply $\mathrm{N}$ and to the greater residual $\mathrm{N}$ accumulation in the soil (Table 3), reflecting a positive response from the nitrogen application through sewage sludge. Similar results were obtained by Silva et al. (1998). No characteristic symptoms of nitrogen deficiency (yellow

Table 5 - Sugarcane yield when cropped in two consecutive years in a soil amended with sewage sludge and vinasse.

\begin{tabular}{lcc}
\hline & Planted-Cane & $1^{\text {st }}$ Ratoon-Cane \\
\hline Control & 125.7 & 105.6 \\
\hline Factorial & 125.5 & 100.0 \\
\hline Sewage sludge (SS) & 124.0 & $106.6^{\mathrm{A}}$ \\
Vinasse (V) & 125.9 & $94.3^{\mathrm{B}}$ \\
SS + V & 126.5 & $99.3^{\mathrm{AB}}$ \\
\hline Furrow/Side of the plants & 125.8 & 99.7 \\
Total area & 125.2 & 100.3 \\
\hline $100 \%$ rate & 124.6 & 98.2 \\
$200 \%$ rate & 126.4 & 101.9 \\
\hline
\end{tabular}

*Uppercase compares means in the same column by the Tukey test at $p<0.005$. older leaves) were observed in any of the treatments for the planted-cane and the $1^{\text {st }}$ ratoon-cane. Thus, sewage sludge was able to supply plant $\mathrm{N}$ requirements.

\section{ACKNOWLEDGMENTS}

To CNPq for funding the research, to SABESP - Franca, for supplying the sewage sludge, and to Santa Inês Distillery Ltd. for conceding the area, supplying vinasse and supporting the study.

\section{REFERENCES}

ANDREOLI, C.V.; DOMASZAK, S.; FERNANDES, F.; LARA, A.I. Proposta preliminar de regulamentação para reciclagem agrícola do lodo de esgoto no Paraná. Sanare, v.7, p.53-60, 1997.

ARAÚJO, A.M.S.; SAMPAIO, E.V.S.B.; SALCEDO, I.H. Mineralização de $\mathrm{C}$ e do $\mathrm{N}$ em amostras de solo cultivado com cana-de-açúcar, ao longo de dez anos com e sem fertilização nitrogenada. Revista Brasileira de Ciência do Solo, v.25, p.43-53, 2001.

BERTON, R.S. Recomendações do uso de lodo de esgotos para algumas culturas. In: CURSO SABESP: uso agrícola de lodo de esgoto., São Paulo: SABESP, 2000. 158p.

CARNAÚBA, B.A.A. O nitrogênio e a cana-de-açúcar. STAB, Açúcar, Álcool e Subprodutos, v.8, p.24-41, 1990.

COOPERATIVA DOS PRODUTORES DE AÇÚCAR E ÁLCOOL COPERSUCAR. 5a Geração de variedades. Piracicaba: COPERSUCAR, 1995. p.16-23. (Boletim Técnico).

DIAS, F.L.F. Efeito da aplicação de calcário, lodo de esgoto e vinhaça em solo cultivado com sorgo granífero (Sorghum bicolor (L.) Moench). Jaboticabal: UNESP/FCAV, 1994. 74p.

GAVA, G.J.C.; TRIVELIN, P.C.O.; OLIVEIRA, M.W.; PENATTI, C.P. Crescimento e acúmulo de nitrogênio em cana-de-açúcar cultivada em solo coberto com palhada. Pesquisa Agropecuária Brasileira, v.36, p.1347-1354, 2001.

GIANELLO, C.; CAMARGO F.A.O.; REICHMANN, E.; TEDESCO, N.J. Avaliação da disponibilidade do nitrogênio do solo estimada por métodos químicos. Revista Brasileira de Ciência do Solo, v.24, p.93-101, 2000.

HUMBERT, R.P. El cultivo de la caña de azucar. 6 ed. México, DF: Editorial Continental, 1984. 719p.

LARA CABEZAS, W.A.R.; TRIVELIN, P.C.O.; SCHIAVINATOJÚNIOR, P.; BOARETTO, A.E. Perdas gasosas de nitrogênio de vinhaça e uréia em solos cultivados com cana-de-açúcar. Revista Brasileira de Ciência do Solo, v.18, p.463-469, 1994.

MARQUES, M.O. Incorporação de lodo de esgoto em solo cultivado com cana-de-açúcar. Jaboticabal: UNESP/FCAV, 1996. 111p. Tese (Livre-Docência).

MELO, W.J. Variação do N-amoniacal e N-nítrico em Latossolo Roxo cultivado com milho (Zea mays L.) e com lablab (Dolichus lablab). Piracicaba: USP/ESALQ, 1974. 104p. Tese (Doutorado).

OLIVEIRA, F.C. Disposição de lodo de esgoto e composto de lixo urbano num latossolo Vermelho-Amarelo cultivado com canade-açúcar. Piracicaba, USP/ESALQ, 2000. 247p. Tese (Doutorado).

OLIVEIRA, F.C.; MATTIAZZO, M.E.; MARCIANO, C.R.; MORAES, S.O. Lixiviação de nitrato em um Latossolo Amarelo distrófico tratado com lodo de esgoto e cultivado com cana-deaçúcar. Scientia Agricola, v.58, p.171-180, 2001.

RAIJ, B. Van.; CANTARELA, H.; QUAGGIO, J.A.; FURLANI, A. M.C. Recomendações de adubação e calagem para o Estado de São Paulo. Campinas: Instituto Agronômico de Campinas, 1996. 285p. (Boletim Técnico, 100). 
ROSSETO, A.J. Cana-de-açúcar, cultivo e utilização. Campinas: Fundação Cargill, 1987. v.2, p.435-504.

SALCEDO, I.J.; SAMPAIO, E.V.S.B.; ALVES, G.D. Mineralização do carbono e do nitrogênio em solo cultivado com cana-de-açúcar. Revista Brasileira de Ciência do Solo, v.9, p.33-38, 1985. SAMPAIO, E.V.S.B.; SALCEDO, I.J.; BETTAMY, J. Dinâmica de nutrientes em cana-de-açúcar. I. Eficiência de utilização de uréia: ${ }^{15} \mathrm{~N}$ em aplicação única ou parcelada. Pesquisa Agropecuária Brasileira, v.19, p.943-949, 1987.

SARRUGE, J.R.; HAAG, H.P. Análises químicas em plantas. Piracicaba: USP/ESALQ, 1974. 56p.
SILVA, F.C.; BOARETTO, A.E.; BERTON, R.S.; ZOTELLI, H.B.; PEXE, C.A.; MENDONÇA, E. Cana-de-açúcar cultivada em solo adubado com lodo de esgoto: nutrientes, metais pesados e produtividade. Pesquisa Agropecuária Brasileira, v.33, p.18, 1998.

TRIVELIN, P.C.O. Utilização do nitrogênio pela cana-de-açúcar: três casos estudados com uso do traçador ${ }^{15} \mathrm{~N}$. Piracicaba: USP/ ESALQ, 2000. 138p. Tese (Livre-Docência).

Received June 30, 2006

Accepted January 07, 2008 